\title{
平判スキッド自動包装機
}

怢丸石製作所営業部 中 野 悦 宏

\section{Auto Skid Packing by Polyethylene Shrink Film}

\author{
Yoshihiro Nakano \\ Maruishi Iron Works Co. Ltd.
}

This machine with a full automatic size change mechanism - the first in this kind of industry - utilizes easy-to-recycle polyethylene film. Also, great wrapping strength obtainable with this machine eliminates the need to use auxiliary packing materials such as wooden top boards and steel- or PP-bands, and so substantial cost reduction can be attained.

\section{1.はじめに}

近年のヨーロッパにおけるリサイクル法と今後の動向を考え, トイツのレーカー社と複数の特許を持ったシュ リンクフイルム式自動包装機の独占的技術提费を行い, 日本国内はもとより東南アジア諸国，オーストラリア， ニュージーランドへも製造眅売することになった。

業界初の全自動サイズ替の高速自動包装機は他に類がなく，リサイクルが容易にできるポリエチレンフイルム を使用する。

また, 特殊なシステムのためシュリンク後の包装強度は非常に高く, 従来使用の木製天板及びバンド等が不要 になり大幅な包装資材コスト低隇が可能となった。無人化出来る全自動または半自動のタイプが選択できる。

\section{2. 平判スキッド自動包装機の特長}

・木製天板とバンドは必要なく，シュリンクフイルムのみで十分な包装強度が得られ荷崩れの心配はない。

・特殊なシステムのため，包装資材コストを大幅に減少できる (20〜 40\%減)。

・高速自動包装機で $(60$ ヶ $/ \mathrm{H})$ 且つ全自動サイズ替えが出来る。

・スキッドの 6 面がフイルムで完全密封できるため, 防水及び紙の水分を一定に保つのでカール对策にも威力 を発揮する。

・ラヘル紙はフイルムの内側に挿入されるためラベル貼付用の糊が不要で, しかもラベル落ち、ラへル污れが ない。

・フイルムは烧却しても無会害でありリサイクルも容易にできる。

・下部木製パレット製品と同時にシュリンク包装されるため，共に完全一体化される。

・納入実績も 7 年間で 35 台を超えている。

\section{3. ドイツ包装廃衰物回避のための政令}

政令施行日：1991年 6 月 21 日

政令実施日：1991年 12 月 1 日

同政令はドイツ国内で包装材の直接原料，包装材を製造，販売するもの及び包装された商品を眅売するものに 包装材の回収，再使用，リサイクルを義務づけるものである。

[同政令の概要]

(1) 政令の目的

環境保護の钼点から以下を目的に本政令が制定された。 
・最低限の容稹, 重量に限定する

・同一商品に再利用できる

・他の用途の材料としてリサイクルする

(2) 規制の对象者

ドイツ国内で以下の業務を営むすへてての業者とする。

・包装製造業者

・眅売業者

(3) 製新関係に問題になる材料

ポリラミネートクラフト紙

ドイッ国内だけでなく、ヨーロッパ全域の新設のスキッド包装は LLDPE(ポリエチレン)シート包装材が $100 \%$ 実施されている。

(4) オランタ，EC 加盟国の動向

オランタ 2000 年目標に検討中

EC 加盟国 1991 年に包装廃衰物に関する指令案がでた。

\section{4. 日本における最近のポリエチレンフイルムのリサイクル業者}

日本でも毎年処理量が多くなるに従って処理業者も增えており，処理能力もアップしている。

東京に本社がるフイルムリサイクル業者では関東地区中心に 9 工場を持っており，現在 1 ヶ月の処理量は約 $2,000 \mathrm{t}$ であり, 主に再生ペレットを生産し眅売している。

生産コストは運赁が一番高いとのことで, 運㶵だけを負担してもらえるなら 3〜 $4 \mathrm{t}$ 集まればフイルムを引取っ てくれる。 
5. レイアウト例
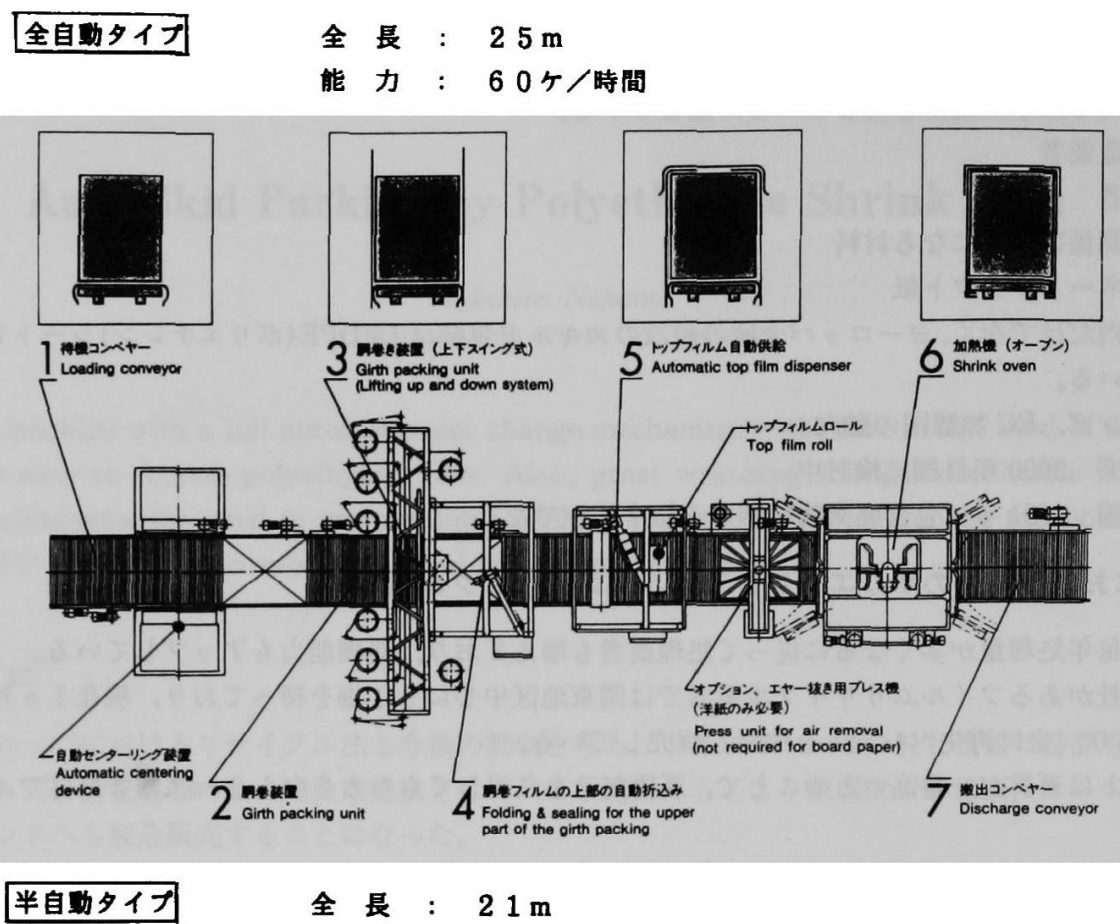

全長: $21 \mathrm{~m}$

能力: $30 \sim 40$ ケ/時間

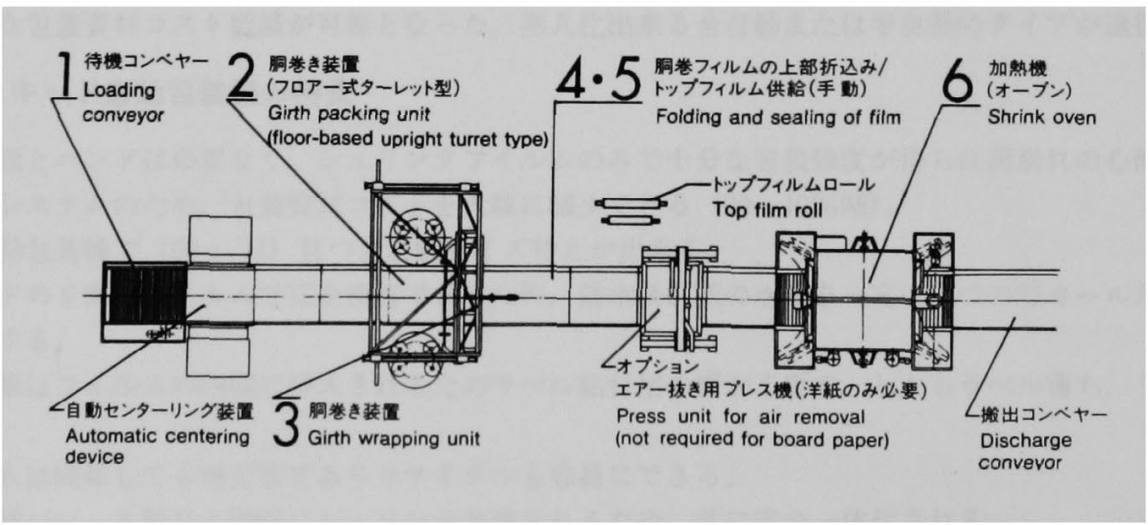




\section{6. 包菱資材の比較}

[丸石シュリンク包装とクラフト包装の比較］（1パレット当り）

(1990 年スイス B 社にて調查)

$$
\begin{aligned}
& \text { パレット 寸 法: } 1,160 \mathrm{mmL} \times 680 \mathrm{mmW} \times 1,210 \mathrm{mmH} \\
& \text { 包装䩚：155 g/m } \\
& \text { シュリンクフイルム: } 155 \mu\left(143 \mathrm{~g} / \mathrm{m}^{2}\right) \\
& \text { トップ及びホトトムフィルム: } 130 \mu\left(120 \mathrm{~g} / \mathrm{m}^{2}\right) \\
& \text { スチールバンド: } 13 \mathrm{~mm} \text { 幅バンド } \times 2 \text { 本 } / 1 \text { 方向 }
\end{aligned}
$$

(1S. $\mathrm{Fr}=80$ 円にて計算)

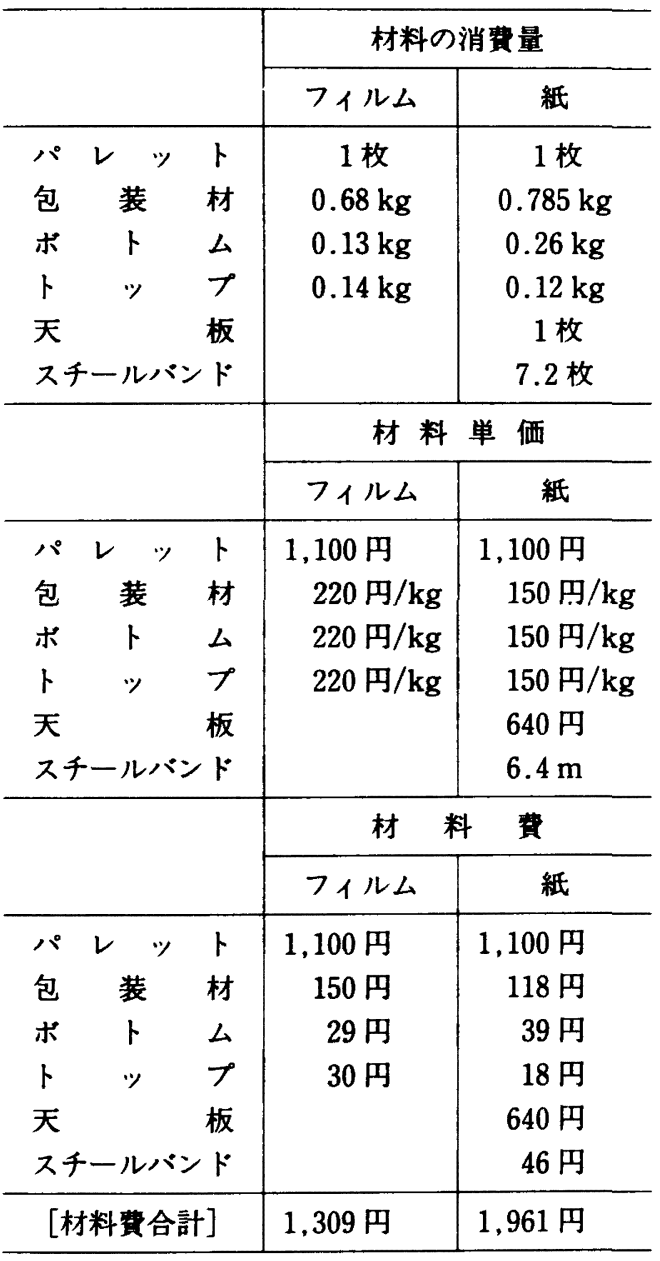

$1,961-1,309=¥ 652 \rightarrow 33 \%$ 安くなる。

例之ば， 1 日に 200 パレット包装した場合 $652 \times 200=¥ 130,400$ の资材費減少となる。 1 年間包装した場合は

\begin{tabular}{|c|c|c|c|}
\hline & & 従来 & 丸石に変更 \\
\hline (1) & 下パレット & 1,250 円 & 1,250 円 \\
\hline (2) & 貼合ボード上下 & 325 円 & ポ 325 円 \\
\hline (3) & ポリワンプ上下 & 67 円 & 117 \\
\hline (4) & 胴巻フィルム & 44 円 & 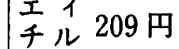 \\
\hline (5) & 胴巻ワンプ & 81 円 & レム \\
\hline (6) & 天板 & 741 円 & \\
\hline (7) & 带鉄 3 本掛 & 40 円 & \\
\hline & & 2,548 円 & 1,784 円 \\
\hline
\end{tabular}

$130,400 \times 300$ 日 $=¥ 39,120,000$ の包装資材費 が節約できる。
[日本の A 社での包装資材比較］ $(800 \times 1,100 \times$ $1,100 \mathrm{H}$ の製品)

従来の包装形態より丸石のスキッド包装にすると， 包装資材コストが 1 パレットで $30 \% ， 764$ 円安く なる。

灾従って包装の手間が減少し, 包装資材の購入, 在庫管理も大幅楽になり保管場所も少なくてす む。 
7. ポリエチレンフイルム使用比較表

ドイツ大手メーカーのデータ

製品 1 パレットに使用するフィルム量

\begin{tabular}{l|c|c|c|c}
\hline & & 丸石カーテンシステム & スパイラルシテム & フードシステム \\
\hline 80 ミクロンフィルム & $\mathrm{g}$ & - & 954 & - \\
\hline 130 ミクロンフィルム & $\mathrm{g}$ & 144 & 144 & - \\
\hline 150 ミクロンフィルム & $\mathrm{g}$ & 680 & - & 1,012 \\
\hline 1 パレットのフィルム重量 & $\mathrm{g}$ & 824 & 1,098 & 1,012 \\
\hline
\end{tabular}

フィルムの価格

( $1 \mathrm{DM}=70$ 円にて計算)

\begin{tabular}{l|c|c|c|c}
\hline & & 丸石カーテンシステム & スパイラルシテム & フードシステム \\
\hline 80 ミクロンフィルム & $\begin{array}{c}\mathrm{DM} / \mathrm{kg} \\
(¥)\end{array}$ & - & $\begin{array}{c}3.35 \\
(234)\end{array}$ & - \\
\hline 130 ミクロンフィルム & $\begin{array}{c}\mathrm{DM} / \mathrm{kg} \\
(¥)\end{array}$ & $\begin{array}{c}3.25 \\
(227)\end{array}$ & $\begin{array}{c}3.25 \\
(227)\end{array}$ & - \\
\hline 150 ミクロンフィルム & $\begin{array}{c}\mathrm{DM} / \mathrm{kg} \\
(¥)\end{array}$ & $\begin{array}{c}3.25 \\
(227)\end{array}$ & $\begin{array}{c}3.25 \\
(227)\end{array}$ \\
\hline 1 パレットに必要なフィルム代 & $\begin{array}{c}\mathrm{DM} / \mathrm{P} \\
(¥)\end{array}$ & $\begin{array}{c}2.79 \\
(195)\end{array}$ & 3.29 \\
\hline 1 年間の生産パレット台数 & $\mathrm{P} / \mathrm{Y}$ & 250,000 & 250,000 & $(230)$ \\
\hline 1 年間のフィルム代 & $\mathrm{DM} / \mathrm{Y}$ & $\begin{array}{c}697,500 \\
(¥)\end{array}$ & $(48,825,000)$ & $\begin{array}{c}915,000 \\
(64,050,000)\end{array}$ \\
\hline
\end{tabular}

丸石カーテンシステムを $100 \%$ とした場合

$\%$

100

100

0

$+2$

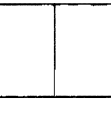

118

\section{8.おわりに}

今迄のスキッドの包装は防湿を第一に考之，次に荷崩れを考えて手間の掛かる包装を行ってきたが，ドイッに てリサイクルの政领が実施されたことによりポリエチレンフイルムを使用して荷崩れしない特殊オーブンがドイ ッのレーカー社にて開発され、ヨーロッパに急速にポリエチレンフイルムのシュリンク包装が普及された。

オーストリーのライカム社では，1日 1,000 tのコート紙をリーム包装したものと裸包装物を全部シュリンク 包装している。

日本の場合も包装材のリサイクルとコストタウンができ，また，全自動運転ができるのでこれからのスキッド 包装にこ協力できることを確信している。 